\title{
Redundant Presses and Recycled Woodcuts: The Journey of Printing Materials from London to Constantinople in the Seventeenth Century
}

DOI:

$10.1086 / 688407$

\section{Document Version}

Final published version

Link to publication record in Manchester Research Explorer

Citation for published version (APA):

Palabiyik, N. (2016). Redundant Presses and Recycled Woodcuts: The Journey of Printing Materials from London to Constantinople in the Seventeenth Century. The Papers of the Bibliographical Society of America, 110(3), 273298. https://doi.org/10.1086/688407

\section{Published in:}

The Papers of the Bibliographical Society of America

\section{Citing this paper}

Please note that where the full-text provided on Manchester Research Explorer is the Author Accepted Manuscript or Proof version this may differ from the final Published version. If citing, it is advised that you check and use the publisher's definitive version.

\section{General rights}

Copyright and moral rights for the publications made accessible in the Research Explorer are retained by the authors and/or other copyright owners and it is a condition of accessing publications that users recognise and abide by the legal requirements associated with these rights.

\section{Takedown policy}

If you believe that this document breaches copyright please refer to the University of Manchester's Takedown Procedures [http://man.ac.uk/04Y6Bo] or contact uml.scholarlycommunications@manchester.ac.uk providing relevant details, so we can investigate your claim.

\section{OPEN ACCESS}




\title{
Redundant Presses and Recycled Woodcuts: The Journey of Printing Materials from London to Constantinople in the Seventeenth Century
}

\author{
Nil Palabiyik
}

$\mathrm{T}$

His article investigates how Nicodemos Metaxas, a priestmonk from the Ionian island of Cephalonia, acquired the necessary skills and experience in typography to run a printing house during a four-year London sojourn in the first half of the seventeenth-century. When Metaxas subsequently moved to Constantinople in 1627 to print books for the use of the Greek-speaking Orthodox population, he brought with him a printing press, two sets of Greek fonts, a small collection of woodcuts, several reams of paper, and two skilled workmen. The article aims to ascertain the provenance of these materials and pinpoint their use prior to and in the aftermath of their transfer to Constantinople. In doing so, the article also proposes to draw a vivid picture of how a newly arrived alien with an aspiration to master the art of printing and to publish foreign-language manuscripts would have fared among the city's master printers, paper merchants, booksellers, and other established members of the book trade.

Julian R. Roberts and Evro Layton first identified Metaxas as the printer of a number of Greek books published in London during the 1620s. As Roberts, Layton, and later Letterio Augliera established, Metaxas, a Greek of noble Byzantine lineage, began his printing career

Nil Palabiyik (15o Deansgate, Manchester, $\mathrm{M}_{3}{ }_{3} \mathrm{EH}$, United Kingdom) is British Academy Postdoctoral Fellow at the John Rylands Research Institute, University of Manchester. She is interested in book history, printing, marginalia, and various cultures of the early modern Mediterranean.

PBSA 110:3 (2016): 273-298 (C) 2016 Bibliographical Society of America.

All rights reserved. 0006-128X/2016/0110-0001\$10.00 
in London, where he produced three volumes forming an exquisite collection of theological and rhetorical works by select Greek scholars and Orthodox clergymen. ${ }^{1}$ He then went on to publish further tracts in Constantinople and in his native Cephalonia.

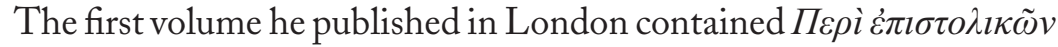

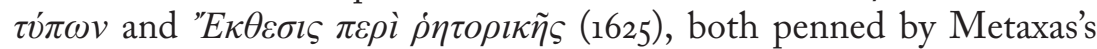
mentor, the eminent Greek philosopher Theophilos Corydaleus. ${ }^{2}$ The second volume was a collection of three tracts on the Procession of the Holy Spirit by post-Byzantine Greek authors. ${ }^{3}$ The third volume was a collection of several tracts centering on doctrinal differences between the Eastern and Roman Churches. ${ }^{4}$ These volumes were printed in the

1. Julian R. Roberts, "The Greek Press at Constantinople and its Antecedents," The Library 22, no. I (1967): 13-43; Evro Layton, "Nikodemos Metaxas, the First Greek Printer in the Eastern World," Harvard Library Bulletin 15 (1967): 140-68; Letterio Augliera, Libri, politica, religione nel Levante del Seicento: La tipografia di Nicodemo Metaxas, primo editore di testi greci nell'Oriente ortodosso (Venice: Istituto veneto di scienze, lettere ed arti, 1996). The $S T C$ does not account for all the tracts Metaxas printed, and on occasion records tracts that were issued together as separate publications. At other instances, they are recorded together under the same number as a single volume. Throughout the article, I refer to volumes published by Metaxas with Legrand numbers as found in Émile Legrand, Bibliographie hellénique ou description raisonnée des ouvrages publiés par des Grecs an XVIIe siècle, 5 vols (Paris: E. Leroux, 1894-1903). For a full bibliographic record of Metaxas's books, see the appendix to my article, "An Early Case of the Printer's Self-Censorship in Constantinople," The Library 16, no. 4 (2015): 381-404.

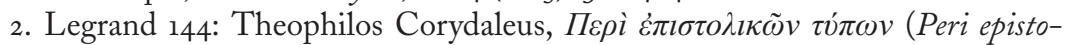
likōn typōn) (Londini: Ex officina G[ulielmi] S[tansby] typographi, MDCXXV);

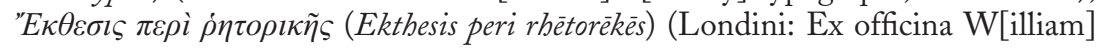
$\mathrm{S}$ [tansby] typographi, MDCXXV); STC 15083.

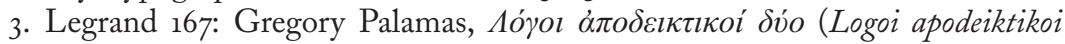

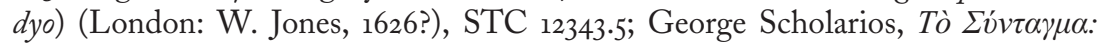

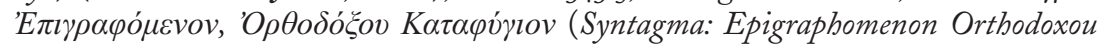
Kataphygion) (London: W. Jones, 1626?), STC 11728.4; Maximos Margounios,

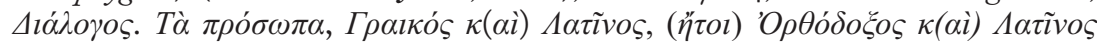
(Dialogos. Ta prosōpa, Graikos kai Latinos ètoi Orthodoxos kai Latinos) (London: W. Jones, 1626?), STC 17697.3.

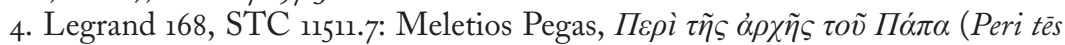
archès tou Papa) (London: Eliot's Court Press, 1627?), STC 19553.5; George Ko-

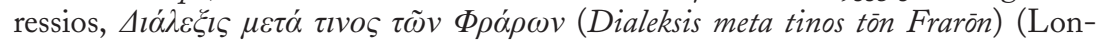

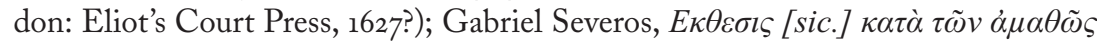

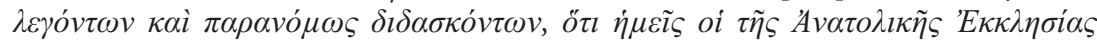

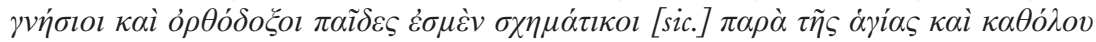


houses of William Stansby, William Jones, and the Eliot's Court Press respectively. Although no books traced to Metaxas were printed by Augustine Matthews, some of Matthews's ornaments and equipment also found their way into Metaxas's inventory. In Constantinople he used the type, ornaments, paper, and printing equipment obtained in London to produce a volume containing two works: Patriarch Cyril Luca-

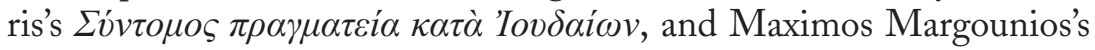

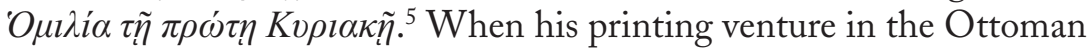
capital came to an abrupt end in 1628 due to complaints of the resident Jesuit fathers, who saw his publications as a threat to their Oriental mission, and the subsequent intervention of the Turkish officials, Metaxas decided to transfer his press once again, this time to Cephalonia, where

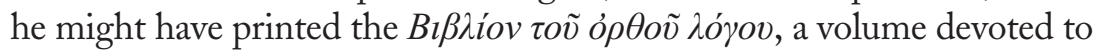
the cult of St. Gerasimos, the patron saint of Cephalonia. ${ }^{6}$

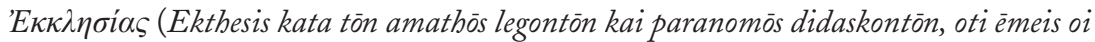
tès Anatolikès Ekklēsias gnèsioi kai orthodoxoi paides esmen schimatikoi para tēs hagias

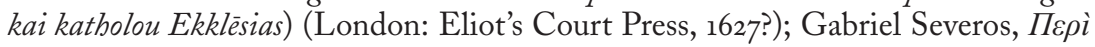

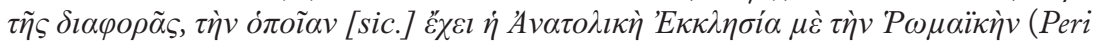
tès diaphoras tèn opoian echei è Anatolikè Ekklèsia me tèn Römaikèn) (London: Eliot's

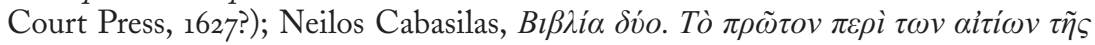

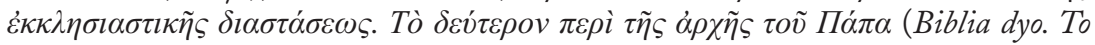
prōton peri tōn aitiōn tès ekklēsiastikès diastaseōs. To defteron peri tēs archēs tou Papa)

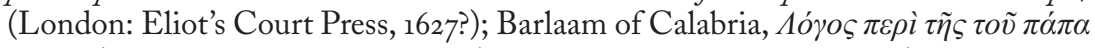

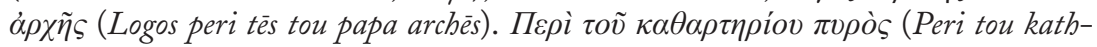
artēriou pyros) (London: Eliot's Court Press, 1627?), STC 4325.5. All titles issued collectively. STC 11511.7 contains all tracts in the following order: Pegas, Coressios, Severos (2 tracts), Cabasilas, Barlaam. STC 19553.5 has Pegas only. STC 4325.5 has Barlaam only.

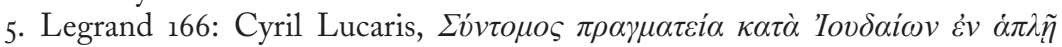

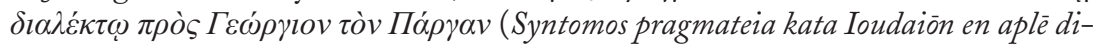

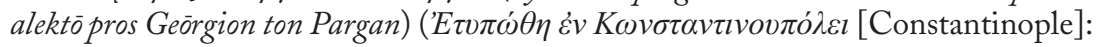

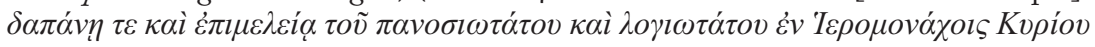

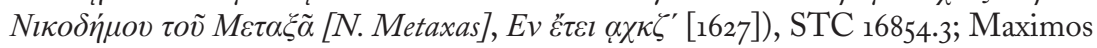

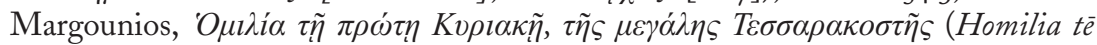
prōtè Kyriakè tès megalès Tesserakostès) (Constantinople: N. Metaxas, 1628).

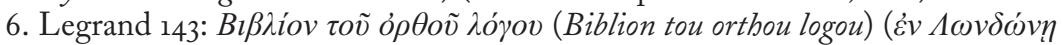

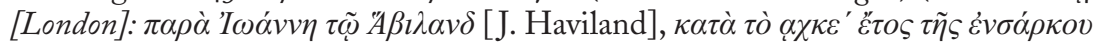

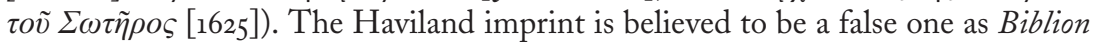
tou orthou logou was not among those found in the crates transferred to Constantinople. Augliera argues that it was printed in Cephalonia after the Constantinople episode. 
Roberts established, through diplomatic reports and typographical evidence, that Legrand 167 and 168 , which were previously thought to have been printed in Constantinople, had indeed been printed in London. Layton made the first attempt to match the initial blocks employed by Metaxas with those that were already in use at London printing houses. While Layton and Roberts linked Metaxas's printing activities to certain houses in London by tracing the type ornaments found in his books, neither of these articles explored his connections with English printing houses in depth. The present study makes a fuller analysis of the initial blocks employed in Metaxas's editions, in addition to examining other bibliographical elements, such as ornaments, typefaces, and paper, in order to determine how Metaxas obtained from London printing houses the equipment, hardware, and other materials that he transferred to Constantinople. Such an inquiry into the material aspects of Metaxas's corpus will not only enable us to map the origin and uses of each typographical element but also help reconstruct Metaxas's place and connections in the world of London book production and printing trade. I derived the evidence for this study from preserved impressions in his books: the emergence of fonts and ornaments in Constantinople and Cephalonia, and their subsequent disappearance from the London printing scene denotes their transfer to Metaxas. I was able to trace all but two pieces he acquired in London, and these transactions offer a truly remarkable glimpse into how printing materials were traded or passed down, when they were not transferred as a whole upon the death or bankruptcy of a printer.

Metaxas landed in England in 1623 with the intention of publishing an epistolary manual contained in a manuscript he brought with him, according to a letter Metrophanes Critopoulos, a fellow Greek priestmonk resident in England, wrote to his Oxford classmate Matthias Turner. $^{7}$ As neither a citizen of London nor member of the Stationers' Company, Metaxas was barred from establishing a printing house or operating a press. Nevertheless, in spite of being an alien, he worked cleverly with members of the printing trade to edit and publish a number of texts, and in the process acquired printing materials he subse-

7. This letter is published and translated in Colin Davey, Pioneer for Unity: Metrophanes Kritopoulos (1589-1639) and Relations between the Orthodox, Roman Catholic and Reformed Churches (London: The British Council of Churches, 1987), 116. 
quently brought with him on his return to Constantinople. Within two years of his arrival, Legrand 144 came out of Stansby's press with the imprint "Londini: Ex Officina G.[ulielmi] S.[tansby] Typographi, 1625." The title page of the volume bears a printer's device depicting a young man with wings on one wrist reaching divine wisdom and holding a girdle book in the other hand, and bearing the motto "Mollia cum duris." A year earlier Stansby had used the same device for De apostasia ecclesiae (1624), "authored and printed at the expense of Christopher Angelos," another Greek priest-monk who had arrived in England in $1608 .^{9}$

The parallels between the early lives of Angelos and Metaxas are striking. They were both schooled at the Athenian Academy, attained the rank of priest-monk in the Greek Orthodox Church, came to England, built connections with English clergy, ${ }^{10}$ and published books in collaboration with English printers in the first half of the seventeenth century. ${ }^{11}$ Angelos was in search of a Latin translator for his De apostasia ecclesiae, which came out in Greek and Latin in 1624, around the same

8. Ronald B. McKerrow, Printers' E Publishers' Devices in England E Scotland 1485-1640 (London: The Bibliographical Society, 1913), no. 393.

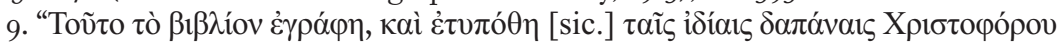

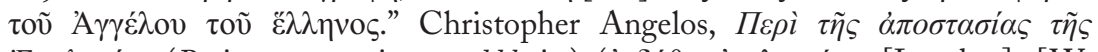

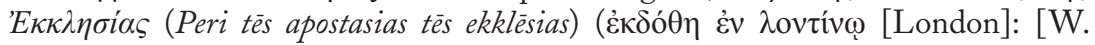
Stansby], $\alpha \chi \kappa \delta^{\prime}$ [1624]); De apostasia ecclesiae (Editus fuit Londini: [W. Stansby], 1624); STC 637, $\mathrm{C}_{2}{ }^{\mathrm{v}}$.

10. In order to earn the sympathy of an English cleric, he dedicated Legrand 144 to John Williams, Bishop of Lincoln with an epistle dated 21 March 1624. It is unclear whether he received any financial support from Williams. An alternate dedication to Pachomios Doxaras, Bishop of Cephalonia and Zakynthos, dated ${ }_{24}$ January 1624, is found in the copies housed in Athens, National Library of Greece

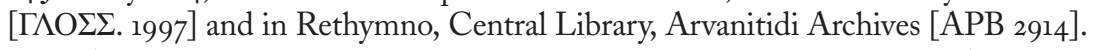

11. Angelos attended the academy according to his own account: "At length I came to Athens, studied \& preached there" (Christopher Angell, a Grecian, Who Tasted of Many Stripes and Torments Inflicted by the Turkes, for the faith which he had in Iesus Christ [At Oxford: Printed by John Lichfield, and James Short, 1618], STC 641, A2 ${ }^{\mathrm{r}}$ ). The Venetian bailo Sebastian Venier noted Metaxas's education in a report dated 4 September 1627: "[S]i dimostra huomo di qualche cognitione di lettere, havendo studiato due anni in Atene e poi quattro in circa nella città di Londra, ove è stato conosciuto dalli Ecc.mi SS.ri Ambasciatori Valaresso e Pesaro.” [He seems a man of some learning, having studied two years in Athens and about four in the city of London, where he was known to the Venetian ambassadors Valaresso and Pesaro.] (Venice, State Archives, Dispacci Constantinopoli, 105.47, ff. $67^{\mathrm{r}}-71^{\mathrm{r}}$, reproduced in Augliera, Libri, politica, religione, 44-48, 45). 
time as Metaxas was looking for a printer for the epistolary manual he had brought with him to London. It seems they both spent some time in Stansby's printing house during that year.

In the absence of a detailed narrative mapping out Metaxas's stay in London, an analysis of Angelos's printing activities will shed much light on the circumstances in which Metaxas is likely to have found himself while publishing Greek books. A prolific author, Angelos sent seven tracts to press between 1617 and 1624, in addition to two broadsheets bearing testimony to his "honest behaviour" undersigned by his $\mathrm{Ox}$ ford and Cambridge friends. Angelos's earlier publications, issued by the university press in Oxford, were popular cheap-prints, short tracts peppered with a lot of drama, revealing the gory details of "the stripes and torments" he supposedly went through during his imprisonment in Athens. These commercially lucrative little pamphlets depicting his "Christian suffering" under the Ottomans provided him with the money he so desperately needed in his new home, but also left him bitter, for he felt that his Oxford printers did not do his works justice.

One drawback of having his works printed in the smaller printing establishment at Oxford University was the poor quality of the woodcut reproductions of images. The 1617 Greek edition of Angelos's autobiographical account of his imprisonment in Athens and escape to England was the first Oxford book to feature illustrations; yet the printers John Lichfield and William Wrench made quite an unimpressive start. ${ }^{12}$ As Percy Simpson demonstrated in his Proof-reading in the Sixteenth, Seventeenth and Eighteenth Centuries, the proof copy for this small quarto preserves the original manuscript drawings depicting the torture Angelos allegedly underwent at the hands of the Ottoman governor of Athens. ${ }^{13}$ The discrepancy between the drawings and the set of cheap

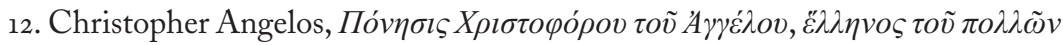

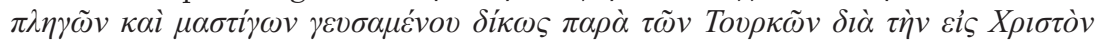

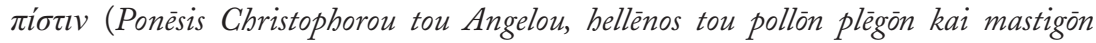
gevsamenou adikōs para tōn Tourkōn dia tèn eis Christon pistin) (At Oxford: Printed by John Lichfeild [sic.], and William Wrench, 1617), STC 638.

13. Percy Simpson, Proof-Reading in the Sixteenth, Seventeenth and Eighteenth Centuries (London: Oxford University Press and Humphrey Milford, 1935), 80. The proof copy with the original drawings and is preserved in the library of Corpus Christi College, Oxford [shelfmark LG.2.10(9)]. Another set of (much less professional) drawings is found in Athens, Gennadius Library, MS 121.1, a manuscript containing the English translation of the same text. 
woodcuts commissioned by the two printers is appalling. The woodcuts, which show no attention to detail whatsoever, reduced the two drawings provided by Angelos to crude sketches. The explanatory notes attached to the images were also left out, leading to further confusion. ${ }^{14}$

In addition to the over-simplification and de-contextualisation of his drawings, Angelos's books also suffered from typographical errors, and more importantly from textual amendments implemented by the correctors without the author's consent. It must have been these and other kinds of haphazardness he suffered at the hands of provincial printers that induced Angelos to move to the capital in 1619 and take charge of his own publishing activities. Unfettered from the editorial interference of his Oxford publishers, he arranged to see his own work through the press at Stansby's printing house, reminiscing bitterly how he had "witnessed the corruption of [his] previous books with [his] own eyes." ${ }^{15} \mathrm{He}$ even warned anyone who dared "to change a point or an accent, or to appropriate the contents, or to manipulate the wording, or to put a different title on the cover of this book." 16

In London Angelos teamed up with Stansby to print at least four books. His preference for Stansby, who was conveniently in possession of a Greek font, comes as no surprise. According to Mark Bland, Stansby's impressive resources in terms of type, labor, and facilities, which "few other printing houses were able to match," as well as his willingness to accommodate the demands of authors and publishers made him a popular trade printer. ${ }^{17}$ The title pages of Stansby's Angelos volumes all bear Cambridge and Oxford imprints, but the ornaments in three books tell a different story:

14. The bad quality woodcuts were recycled for the English translation which was printed the same year (Christopher Angell, a Grecian, Who Tasted of Many Stripes and Torments Inficted by the Turkes for the Faith which He had in Christ Iesus [At Oxford: Printed by John Lichfield, and William Wrench, 1617], STC 639).

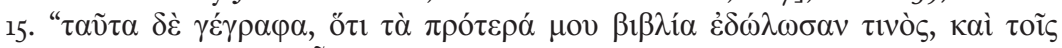

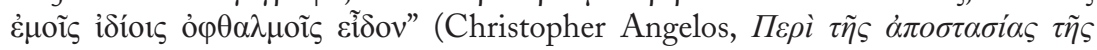

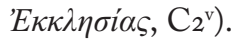

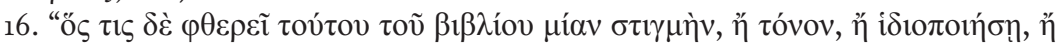

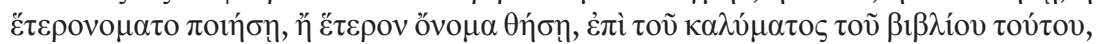

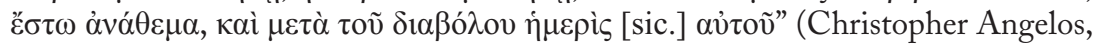

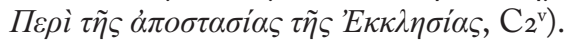

17. Mark Bland, "William Stansby and the Production of The Workes of Beniamin Jonson, 1615-16," The Library 10, no. 1 (1998): 6, 10. 
An Encomion of the famous Kingdom of Great Britain (At Cambridge: Printed by Cantrel Legge [i.e., London: W. Stansby], 1619), STC 635. Stansby ornaments:

Headpiece $[26 \times 85 \mathrm{~mm}$ ], title page, intricate design with a crowned Scottish thistle on left-hand side, a plumed Tudor rose on the right and a fleurde-lis in the middle sided by a rose and a thistle (also appears in Legrand 144 's title-page).

Headpiece $[18 \times 72 \mathrm{~mm}], \mathrm{A}_{3}{ }^{\mathrm{r}}$, three satyrs in a rustic setting (also appears in STC $\left.637, \mathrm{~B}_{4} \mathrm{v}\right)$.

Borderpiece $[4 \times 76 \mathrm{~mm}], \mathrm{A}_{4}^{\mathrm{v}}$ and $\mathrm{Br}^{\mathrm{r}}$, four foliated and dotted ribbons curled at each end (also appears in Legrand $\left.144, \boldsymbol{\Upsilon}_{1}{ }^{\mathrm{r}}\right) .^{18}$

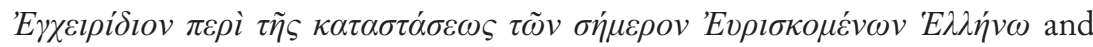
Enchiridion de institutis Grecorum (Ex officina Cantrelli Legge, Academiae Cantabrigiensis typographi [i.e. London: W. Stansby], 1619), STC 636. Stansby ornaments:

Printer's device $[39 \times 27 \mathrm{~mm}$ ], McKerrow no. 252 , on both title pages.

Headpiece $\left[26 \times 85 \mathrm{~mm}\right.$ ], first tract only, $\mathrm{A}_{2}{ }^{\mathrm{v}}$ (same as STC 635 title-page headpiece).

Headpiece $\left[26 \times 85 \mathrm{~mm}\right.$ ], first tract only, $\mathrm{A}_{3}{ }^{\mathrm{r}}$, a man flanked by two hounds and two birds of prey on each side.

Tailpiece $\left[30 \times 80 \mathrm{~mm}\right.$ ], first tract only, $\mathrm{A}_{3}{ }^{\mathrm{v}}$, design with a satyr.

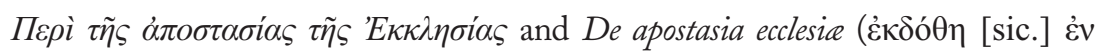

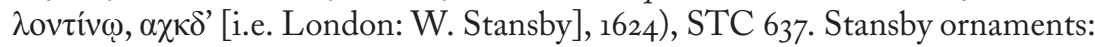

Printer's device [ $34 \times 34 \mathrm{~mm}$ ], McKerrow no. 393, title page (also appears in Legrand 144, title page).

Headpiece $[13 \times 74 \mathrm{~mm}$ ], title page, Gorgon head and serpents in the middle, and two sets of cornucopias abundant with fruit on both sides.

Christopher Angell, a Grecian, Who Tasted of Many Stripes and Torments Inflicted by the Turkes for the Faith which he had in Iesus Christ (At Oxford: Printed by John Lichfield, and James Short, 1618 [i.e. London: W. Stansby, 1620? ${ }^{\text {219] }}$ ), STC 641. Stansby ornament:

Tailpiece, title page, cherub's head with crossed wings [ornament not measured].

The London translation of Angelos's autobiography came with numerous subtle but important changes revealing the extent of his editorial

18. A year earlier Stansby included this ornament in his portion of Daniel Dyke's Two Treatises (STC 7410 ) on $\mathrm{C}_{4} \mathrm{v}, \mathrm{G}^{\mathrm{v}}$, and $\mathrm{K}_{2} \mathrm{v}$, and here the crack on the right bottom corner was smaller.

19. Includes reprint of 1618 tract but also contains letter dated 3 July 1620. 
interference. The book's title became Christopher Angell, A Grecian, who tasted of many stripes and torments inflicted by the Turkes for the faith which he had in Iesus Christ (as opposed to Christ Iesus of the previous edition). The text of Angelos's "An Epistle in Commendations of England and the Inhabitants Thereof," which previously only contained references to Oxford and Cambridge, was made more relevant to its intended readership with added references to London and the River Thames. Furthermore, Angelos italicized proper names and quotations in the main text, made sure that new and improved woodcuts were used, added captions explaining the symbolic meaning of the illustrations beneath the images, and appended letters of testimonials to the back of his book.

As was often the case in the early modern London book trade, Angelos participated in the proofing of his publications. His errata for Enchiridion de institutis Gracorum includes an apologetic note acknowledging that he knew "little Latin" and that "many errors surely must have remained." ${ }^{20}$ Possibly during his visits to Stansby's house Angelos made the acquaintance of Samuel Purchas, who was having his Microcosmus printed there. ${ }^{21}$ In 1625 Purchas described him as "Christopher Angelos a Greeke Monke and Priest, which hath liued many yeeres in England, and some fiue years since gaue mee a Greeke Booke printed by him in London, touching their present Rites, both in their Churches and Monasteries" in a preface to a ten-page excerpt from Enchiridion de institutis Gracorum which he had translated into English. ${ }^{22}$ In 1624, Angelos was again proofreading, and his Latin admittedly had not measurably improved. While he was able to detect nearly sixty errors in the Greek text, he recorded only six errors from the first sheet of the Latin text before giving up entirely after five pages. It is possible that Angelos and Metaxas met at Stansby's printing house during this time, when work may already have begun on Metaxas's first book, Legrand 144 .

Thus far this article has tried to portray the editorial complications of publishing Greek books in London at the beginning of the seventeenth century by introducing readers to the enterprise of Angelos. The

20. "Errata siqua alia, qua certè plurima ... proptere à quod ego linguam Latinam minimè calla rem" $\left(\mathrm{G}_{3}^{\mathrm{v}}\right)$.

21. Samuel Purchas, Purchas his Pilgrim. Microcosmus, or the History of Man (London: Printed by W. Stansby for Henry Fetherstone, 1619), STC 20503.

22. Samuel Purchas, Purchas his Pilgrims in Five Books (London: Printed by William Stansby for Henry Fetherstone, 1625), STC 20509, O $^{\mathrm{r}}$. 
lives and experiences of Angelos and Metaxas have commonalities on many different levels, including their shared ethnic origin, native tongue, theological education, and interest in publishing. Therefore, the precedent set by Angelos sheds much valuable light on the conditions Metaxas most certainly faced when he ventured out to publish Greek books in London. In the remaining part, my focus will be on the mechanical, financial, and organizational aspects of Metaxas's printing enterprise.

Like Angelos, who proudly put his name down on his colophons as the financier of his books, Metaxas relied mostly on his own purse to publish. While Angelos hoped and-judging by the multiple editions of his autobiography - succeeded to some extent to make a return from the publication of his books, Metaxas's enterprise was essentially charitable. Sir Thomas Roe, the English ambassador in Constantinople, described Metaxas's motives thusly: "He brought with him the Greeke stampe, made at his expence, and diuers books printed in England, as he pretended, for the benefitt of his church, drowned in invincible ignorance; especially for want of meanes to learne and studye." ${ }^{23}$ Roe stated that the equipment and books cost Metaxas " 7,000 dollers," an estimate also confirmed by the Venetian bailo, Sebastian Venier who reported that Metaxas, "out of zeal for his rite, has ventured 7,000 to 8,000 reals with great risk of non-recovery, if he [did recover, it would be] a long and difficult [process]."24

Metaxas's self-funded status demonstrably gave him greater independence as to what went into the books he produced. He put his stamp on his editions by penning epistles to the reader and dedicatory letters to worthy patrons, preparing contents tables, indices, and errata lists, as well as compiling sample letters and quotations, and editing and correcting texts for print. He conceivably spent a long time in the printing houses of London, where he not only observed the working practices of a printing business but also influenced the considerations that went into the physical production of the books he published. The use of Greek

23. The negotiations of Sir Thomas Roe, in his Embassy to the Ottoman Porte, from the Year 1621 to 1628 inclusive (London: Printed by Samuel Richardson, 1740), 760.

24. Negotiations, 762 . Venier wrote of Metaxas, "si attrovi interasssato per zelo del suo rito di sette di otto mille reali, con gran rischio di non potersene rimborsare se non con lunghezza et difficoltà" (4 September 1627, Venice, State Archives, Dispacci Constantinopoli, 105.47, ff. $67^{\mathrm{r}}-7 \mathrm{1}^{\mathrm{r}}$, reproduced in Augliera, Libri, politica, religione, 44-48, 46). 
signing in Legrand 144 instead of the usual Latin is a probable sign of Metaxas's involvement in the printing process. I have not seen any other examples of this practice in Stansby's books (or in any other Greek book printed in London in the same decade, for that matter), and Stansby certainly did not use Greek signatures for Angelos's books. The practice of using letters as numbers in signatures has its roots in the Byzantine manuscript production, a tradition continued by Venetian printers of Greek incunabula. ${ }^{25}$ Coming from the Venetian-controlled Ionian islands, where-despite the proliferation of printed texts elsewhere in Europe-manuscript transmission of Greek texts was still the norm during the first half of the seventeenth century, Metaxas would have been naturally inclined to retain the conventions of scribal production.

In order to obtain the materials and the equipment necessary to furnish his planned printing house in Constantinople, Metaxas collected a variety of printing paraphernalia during the four years he spent in London. A bibliographical analysis of the books he produced in collaboration with London printers will enable us to pinpoint where and when he gathered the blocks, type, and paper stocks he used in Constantinople. The investigation will begin with paper, not only because it was the most expensive component of book production but also because it was possibly the first item Metaxas purchased.

The paper in Metaxas's printed books feature a single watermark, and the color, texture, and thickness are consistent throughout, which suggests that he bought paper from a single retailer and supplied the same make of paper to the different printers he worked with. The watermark found in Metaxas's books depicts a fleur-de-lis encircled by a crown adorned with a smaller fleur-de-lis and pearls. Below the crown, the initials "I. G." and two stars are seen. ${ }^{26}$ This is a class of watermark

25. The editors of a recent incunabula catalogue did notice that "some Greek books ... have signatures printed in Greek, but then with Greek letters rather than any sort of numbers" (A Catalogue of Books Printed in the Fifteenth Century now in the Bodleian Library, ed. by Alan Coates, Kristian Jensen, Cristina Dondi, Bettina Wagner, and Helen Dixon [Oxford: Oxford University Press, 2005], lxxx). What they failed to note is that the Greek letters are numbers, as each Greek character carries a numerical value $(\alpha=1, \beta=2, \gamma=3 \ldots 1=10, \kappa=20, \lambda=30$, etc.), and this is how Byzantine scribes paginated and dated their manuscripts for centuries.

26. No. 2 in the watermarks inventory in Eric Rasmussen and Anthony James West, eds., The Shakespeare First Folios: A Descriptive Catalogue (Basingstoke: Palgrave Macmillan, 2012), 883. 
found in French paper commonly used in English books of the first half of the seventeenth century. According to John Bidwell, English printers depended on imported paper until the end of the seventeenth century, French paper having the greatest market share, larger than imports from all other countries combined..$^{27}$ Roberts attributes the production of Metaxas's paper to Jean Ganne of Vire, Calvados, without providing any explanation as to why. However, Edward Heawood maintains that "I. G." may refer to any other French manufacturer with the same initials, such as Jean Gros of Périgord. ${ }^{28}$

Now that we have established that Metaxas bought French crown paper from a London merchant in the first part of the 1620 , we may arrive at an estimate of how many reams he used to print all the books he produced and how much he paid for them. It appears that at the very beginning of his printing venture, the inexperienced Metaxas tied up most of his capital in a large stock of paper with which he produced in London Legrand 144 (a 13-sheet octavo), Legrand 167 (a $65^{1 / 2}$-sheet quarto) and Legrand 168 (a 25 $5^{1 / 2}$-sheet quarto). Using the same paper, he also printed, in Constantinople and Cephalonia, Legrand 166 (a $281 / 2$-sheet quarto) and Legrand 143 (a 2 -sheet octavo), respectively. To find out the exact number of reams needed to print these volumes, we need to establish the size of his entire production.

Metaxas did not leave behind any ledgers or balance books; yet the reports of the European representatives in Constantinople indicate that his print runs were sizable, and indeed measured in the thousands. The French ambassador Philippe de Harlay, Comte de Césy wrote to Philippe Béthune on 27 April 1628 that "3,000 copies" of Legrand 166, "a book against the Jews in Greek vernacular . . . bearing on its first page the arms of England with [the motto] honi soit qui mal y pense" were printed

27. John Bidwell, "French Paper in English Books," in The Cambridoe Historv of the Book in Britain Volume 4: 1557-1695, ed. John Barnard and Donald F. McKenzie (Cambridge: Cambridge University Press, 2002), 583-6o1.

28. Edward Heawood, Watermarks, Mainly of the 17 th and 18 th Centuries (Hilversum: Paper Publications Society, 1950), 87. On the initials "I. G.” see Edward Heawood, "Papers Used in England after 1600: I. The Seventeenth Century to c. 1680," The Library 11, no. 3 (1930): 271-72 and 287. 
and sent to many places. ${ }^{29}$ Referring to the crates of printed books Metaxas brought from London in June 1627, Sebastian Venier reported that "many cases of Greek books" had passed through the customs, and further remarked that "the number of books [was] considerable". ${ }^{30}$ The crates also included copies of Legrand 144. Produced in a format suited to educational purposes and intended for a learned readership, this volume was used as a textbook in Greek schools all over the Mediterranean and the Balkans for over a hundred years, until a new edition came out in $1744 .{ }^{31}$ Judging from its popularity and impact, this edition must have also been printed in a large run. Legrand 144 survives in only twentyone copies today, but one should not be misled by this rather small survival rate, as there is often no direct correlation between the number of extant copies and the edition size of an early printed book. Donald F. McKenzie has argued that educational material, in particular, tends not to stand the test of time due to their heavy use despite the enormous quantities pushed into the market. ${ }^{32}$ Today, merely two copies of Legrand 144 survive in Greece, whereas Britain boasts eleven copies. ${ }^{33}$

29. "car Cyrille ... fist mettre sur la presse un livre contra hebraeos en grecq vulgaire dans lequel il glisse plusieurs heresies et au premier feuillet du livre les armes d'Angleterre avecq un honny soie il qui mal y pense, en taille doulce, livre qui en dix jours fust tellement debité que plus de trois mille exemplaires furent semez de toutes partz" (in Georg Hofmann, Griechische Patriarchen und römische Päpste. Untersuchungen und Texte, II.I: Patriarch Kyrillos Loukaris und die römische Kirche, Orientalia Christiana vol. 15, no. 1 [Rome: Pontificium Institutum Orientalium Studiorum, 1929], 67-69, 67.)

30. "molte casse de libri greci . . . il numero de libri sia considerabile" (4 September 1627 , Venice, State Archives, Dispacci Constantinopoli, 105.47, ff. $67^{\mathrm{r}}-71^{\mathrm{r}}$, reproduced in Augliera, Libri, politica, 44-48, 45, 46).

31. For the use of this edition as a textbook, see Cléobule Tsourkas, Les débuts de l'enseignement philosophique et de la libre pensée dans les Balkans: La vie et l'oeuvre de Théophile Corydalée, 1570-1646 (Thessaloniki: Institute for Balkan Studies, 1967), 101.

32. Donald F. McKenzie, "Printing and Publishing 1557-1700: Constraints on the London Book Trades," in The Cambridge History of the Book in Britain Volume 4: 1557-1695, ed. John Barnard and Donald F. McKenzie (Cambridge: Cambridge University Press, 2002), 559-6o. Also see Philip Gaskell, A New Introduction to Bibliography (Oxford: Oxford University Press, 1972), 162-63.

33. The copies in Greece are National Library of Greece $[\Gamma \Lambda \Omega \Sigma \Sigma$. 1997] and University of Crete Library [APB 2914]. The copies in Britain are London, British Library [236.h.25]; London, St. Paul's Cathedral Library [no shelfmark]; 
It comes as no surprise that the thousands of copies distributed as textbooks were lost (though some may remain unrecorded), when the few copies sent to English clergy as gifts remain intact centuries later. To an English audience, an epistolary manual in Attic Greek was an exotic possession, much prized but little used.

The reports of the ambassadors suggest that Metaxas undertook the printing of long runs, and early modern printing practices do not contradict this proposition. W. W. Greg documents that from 1586 until 1637, edition quantities were limited by decree to 3,000 copies for textbooks, catechisms, and grammars. ${ }^{34}$ Yet these rules were often overlooked, and Metaxas's books were destined for a foreign market and thus unlikely to attract the attention of the Stationers' Company. ${ }^{35}$ Essentially, there was no practical restriction to the number of printed copies Metaxas could print other than the size of the capital investment, and, as it seems, he devoted a handsome amount to his educational endeavor. As his was a charitable venture, Metaxas did not have to worry about the sale of his books or the profit margins, but he must at least have calculated the cost of paper and labor for each of his editions to see how far his money would stretch. If we are to take Harlay's report of 3,000 copies of Legrand 166 as a correct estimate for each volume Metaxas published, he would have used up approximately $805^{1 / 2}( \pm 3 \%)$ reams of paper, including those set apart for non-usable sheets, cancels, and errors. The table below gives a breakdown of resources to produce a single copy of each edition and the total number of impressions made and reams used for an average print run of 3,000 copies.

Cambridge, Trinity College Lower Library [Grylls 32.84]; Cambridge University Library [Rare Books, Syn.8.62.25]; Cambridge, Emmanuel College [S11.4.46 (3)]; Durham, Palace Green Library [SB 2394]; Oxford, All Souls College Library [g.16.12(2)]; Oxford, Bodleian Library [ $8^{\circ} \mathrm{T}$ AA.Seld.]; Oxford, Jesus College Library [L.12.24]; and Oxford, Queen's College Library [BB.a.813].

34. W. W. Greg, ed., A Companion to Arber: Being a Calendar of Documents in Edward Arber's Transcript of the Registers of the Company of Stationers of London, 1554-1640, with Text and Calendar of Supplementary Documents (Oxford: Clarendon Press, 1967), 43, 94-95.

35. Gaskell, A New Introduction, 162. 
TABLE 1

Metaxas's paper consumption

\begin{tabular}{lccc} 
Edition (Format) & Edition Sheets & Total Impressions & Total Reams \\
\hline Legrand $144\left(8^{\circ}\right)$ & 13 & 78,000 & 78 \\
Legrand $167 \mathrm{a}\left(4^{\circ}\right)$ & 15 & 90,000 & 90 \\
Legrand $167 \mathrm{~b}\left(4^{\circ}\right)$ & 40.5 & 246,000 & 243 \\
Legrand $167 \mathrm{c}\left(4^{\circ}\right)$ & 10 & 60,000 & 60 \\
Legrand $168 \mathrm{a}\left(4^{\circ}\right)$ & 4.5 & 30,000 & 27 \\
Legrand $168 \mathrm{~b}\left(4^{\circ}\right)$ & 1.25 & 6,000 & $7 \cdot 5$ \\
Legrand $168 \mathrm{c}\left(4^{\circ}\right)$ & 6.5 & 42,000 & 39 \\
Legrand 167, errata $\left(4^{\circ}\right)$ & 1 & 6,000 & 6 \\
Legrand $168 \mathrm{~d}\left(4^{\circ}\right)$ & 7 & 42,000 & 42 \\
Legrand $168 \mathrm{e}-\mathrm{f}\left(4^{\circ}\right)$ & 5 & 30,000 & 30 \\
Legrand $166 \mathrm{a}\left(4^{\circ}\right)$ & 13.5 & 84,000 & 81 \\
Legrand $167 \mathrm{~b}\left(4^{\circ}\right)$ & 15 & 90,000 & 90 \\
Legrand $143\left(4^{\circ}\right)$ & 2 & 12,000 & 12 \\
Total reams: & & & 805.5
\end{tabular}

How much would Metaxas have had to spend on paper? Much of the paper sold in the English market until the end of the seventeenth century was imported, mainly from Normandy and Brittany. ${ }^{36}$ Paper was sold in reams, a standard unit of measure in papermaking, containing 480 to 500 sheets. ${ }^{37}$ In seventeenth-century London, the import trade was in the hands of six or eight merchants, a group small and powerful enough to fix prices and restrain competition. Obviously, there was little incentive to bring prices down. ${ }^{38}$ The retail price of paper was often subject to fluctuations as a shortage of foreign imports could always have led to a sharp increase in paper costs; besides prices between different sizes and qualities varied considerably. In 1622, Cantrell Legge, the university printer at Cambridge, charged 13s. $4 \mathrm{~d}$. per ream for fine and 8 s. per ream for cheap paper without indication of size. ${ }^{39}$ According

36. Bidwell, "French Paper in English Books," 583.

37. Ibid., 587. Gaskell notes that "480 sheets were the norm in England and Holland," whereas Italian and French mills had a standard of "5oo sheets, consisting of 20 quires of 25 sheets folded in half for storage" (A New Introduction, 59 ). Not all the sheets were perfect, and those that were inadequate for printing would be placed in the outer part of the packaging to protect the inner sheets.

38. Bidwell, "French Paper in English Books," 588.

39. Sheila Lambert, "Journeymen and Master Printers in the Early Seventeenth Century," Journal of the Printing Historical Society 21 (1992): 23. There was no 
to the figures derived from the contemporary records of a deal between the publisher Thomas Walkley and the printer John Beale for the 1620 publication of George Wither's Works, a ream of crown paper (approximately $51 \times 38 \mathrm{~cm}$ ) was priced at $4 \mathrm{~s} .6 \mathrm{~d} .{ }^{40}$ A similar figure emerges from Peter Blayney's calculations of the unit cost of the First Folio of Shakespeare, which is printed on the same quality crown paper (with the majority of sheets featuring the same watermark) as Metaxas used ${ }^{41}$ If he indeed paid 4s. 6d. per ream, he would have spent approximately $£ 186$ 15s. in cash for paper.

Once Metaxas secured his supply of paper, he needed to purchase fonts and type ornaments to take with him to Constantinople. The typeface employed for Legrand 144 is an $82 \mathrm{~mm}$ pica Greek, which is documented to have been first used by John Day in London in $1578 .{ }^{42}$ It looks very similar to Pierre Haultin's $76 \mathrm{~mm}$ small pica, which was often cast on a pica body $(77-88 \mathrm{~mm})$ and referred to as the "cicero of mediane." ${ }^{33}$ Indeed, Day had the opportunity to buy these from Jerome Haultin, the punch cutter's nephew who had settled in London in 1574 and opened a typefoundry soon after. ${ }^{44}$ However, the type used by Day, Stansby, and many other London printers has an -os ligature

difference in terms of price between buying directly from a merchant or relying on your printer for the paper supply since when the printer supplied the paper, he would charge the retail price per ream without any mark-up.

40. The figures are quoted in Bidwell, "French Paper in English Books," 587.

41. Peter Blayney, The First Folio of Shakespeare (Washington, DC: Folger Library Publications, 1991), 25-28.

42. On Day's Greek fonts see, Daniel B. Updike, Printing Types, their History, Forms, and Use; a Study in Survivals, 2 vols. (Cambridge, MA: Harvard University Press, 1951), 2:92; Robert Plomer, A Short History of English Printing 1476-1900 (London: Taylor \& Francis, 1927), 77. Christopher L. Oastler, John Day, The Elizabethan Printer (Oxford: The Oxford Bibliographical Society, 1975), 43, reproduces Day's Greek types.

43. Reproductions from a Specimen of Plantin's Types compiled about 1579 (Oxford: Printed by Charles Batey at the University Press, 1955).

44. On Jerome Haultin's London career, see Henry Carter, A View of Early Typography up to about 1600 (London: Hyphen, 2002), 94; Colin Clair, "Refugee Printers and Publishers in Britain during the Tudor Period," Proceedings of the Huguenot Society of London 22 (1976), 125; David McKitterick, A History of Cambridge University Press, Volume I: Printing and the Book Trade in Cambridge, 1534-1698 (Cambridge: Cambridge University Press, 1992), $5^{8}$. 
with a straight middle line, different from that of Haultin's small pica with a curled up -os ligature cast from the matrices preserved at the Plantin-Moretus Museum in Antwerp. Another character that distinguishes the original font from the London version is the $-\alpha$ ligature that curls upwards following the ending iota. ${ }^{45}$ The evidence suggests that the font that features in Legrand 144 is either Haultin's small pica with variant ligatures cut in England or a close imitation of it. As none of the ornaments used in Legrand 144 appeared in Metaxas's Constantinople books, it would be safe to assume that he did not buy any from Stansby and that his professional relationship with Stansby had come to an end at this point. For reasons that are unknown to us, Metaxas sought the help of other printers for his later publications.

To produce his second book, Metaxas seems to have moved his printing activities to William Jones's house in Redcross Street. Roberts and Layton both attribute Legrand 167 to Jones, albeit without specifying whether they refer to the father or the son. ${ }^{46}$ William Jones the Elder's apprenticeship to John Windet partially overlapped with that of Stansby's, and he set up his own business in $1601 .^{47}$ Specializing in mathematical books, Jones printed the 1620 bilingual edition of Euclid's Elements featuring an initial $\Pi[28 \times 28 \mathrm{~mm}]$ with a lute design. ${ }^{48}$ Jones is the only London printer known to have held this piece in his stock, and the block had been completely forgotten until Metaxas purchased it, added it to his inventory, and printed with it in Constantinople. ${ }^{49}$ The printer's device depicting an anchor with foliage and bearing the motto "Floreat in aeternum" appears for the first time on the title page of Legrand 167, with the implication that it was William Jones the Younger's first issue and that the young man employed the anchor device to distinguish his work from his father's. ${ }^{50}$ The anchor device was employed later in 1635 in Schindler's Lexicon pentaglotton, which shows that

45. Haultin's small pica is reproduced in Hendrik D. Vervliet, Paleotypooraphy of the French Renaissance, 2 vols. (Brill: Leiden, 2008), 1:404.

46. Roberts, "The Greek Press," 2o; Layton, "Nikodemos Metaxas," 156.

47. On William Jones the Elder's career, see Mark H. Curtis, "William Jones:

Puritan Printer and Propagandist," The Library 19, no. 1 (1964): 38-66.

48. STC $10559, \mathrm{H}_{1}^{v}$.

49. Jones died in 1626 and left his business to his son of the same name.

50. $87 \times 66 \mathrm{~mm}$, McKerrow 423 . 
this woodcut never made it into Metaxas's inventory. ${ }^{51}$ In all, Metaxas acquired two ornaments from Jones:

Initial " $"(28 \times 28 \mathrm{~mm})$, a Greek initial with lute design. It last appeared in a Jones book on $\mathrm{H}^{\mathrm{v}}$ of Euclid's Elementorum Euclidis libri tredecim (1620), STC 10559. Metaxas used in on $\mathrm{Al}_{1}^{\mathrm{r}}$ of Legrand 167a (London, 1625 ?) and $\mathrm{B}_{2}{ }^{\mathrm{r}}$ of Legrand 143 (Cephalonia, 1627-28).

Initial "T" $(22 \times 22 \mathrm{~mm})$, a rustic initial featuring wheat stalks and fruits. The last uses by Jones are on A6 $6^{\mathrm{r}}$ of Thomas Scott's The Second Part of Vox Populi (1624), STC 22014, and A1 ${ }^{\mathrm{r}}$ of Christoper Levett's A Voyage Unto New England (1624), STC 15553.5. ${ }^{52}$ Metaxas used it on $\mathrm{N}_{3}{ }^{\mathrm{r}}$ of Legrand $166 \mathrm{a}$ (Constantinople, $1627^{-28}$ ).

Legrand 167 features three sizes of lower-case fonts. For chapter headings, Robert Granjon's $133 \mathrm{~mm}$ paragon is used. It is a complete set that perfectly matches all the key letters and ligatures (a descending $-\alpha$ ligature, slightly wider $\varphi$ with a rounder alternative, terminal -o $\varsigma$ ligature with a curled up stem, round $\beta$ with equal bowls and pointed $\theta$ with a rounder alternative, etc.) found in the matrices preserved at Oxford University Press. ${ }^{53}$ The main text is printed with Haultin's $96 \mathrm{~mm}$ english Greek cast on a $114 \mathrm{~mm}$ great primer body. Both of these typefaces were in the possession of William Jones the Younger at the time, as his father had printed Euclid's Elements and Proclus's Spheres using these two fonts in $1620 .{ }^{54}$ From 1626 onwards, Haultin's english sorts cast on great primer do not appear again in Jones's books, since Metaxas purchased this set and transferred it to Constantinople to print Legrand 166. The third typeface, which only appears in the errata, is the Haultin-like small pica (same as Day and Stansby's but cast on an $87 \mathrm{~mm}$ body).

The errata list for Legrand 167 was not printed in Jones' printing house but at the Eliot's Court Press at a later date together with Legrand

51. STC 21817.5. For more on the printing history of Schindler's Lexicon, see Stephen K. Jones, “The History of a Hebrew Lexicon," The Library 5, no. 4 (1914): 410-23.

52. One may be misled by the initial T's appearance in STC ${ }_{15554}, \mathrm{Ar}_{1}^{\mathrm{r}}$; but this book is only a re-issue of STC 15553.5 (1624) with a new title page dated 1628 .

53. The specimen for the Oxford matrices is found in Stanley Morison, John Fell: The University Press and the 'Fell' Types (Oxford: Clarendon Press, 1967), 98-103. 54. STC 10559 and 20398. 
168d. ${ }^{55}$ The errata and the main text of Legrand 168 are both printed with the Haultin-like $87 \mathrm{~mm}$ pica Greek, also used in the marginal notes of Legrand 166. The $114 \mathrm{~mm}$ great primer Greek Metaxas had bought from Jones earlier is employed for chapter headings of all three books.

Three ornaments link the printers who used the Eliot's Court Press imprint with Metaxas:

Foliated initial "A" (13×13 mm). It appears in: John Boys, Works (1622), STC $345^{2},{ }_{4} \mathrm{O}_{3}^{\mathrm{r}}$; Joseph Hall, Works (1628), STC ${ }_{126} 637, \mathrm{C}^{\mathrm{r}}$. Metaxas used it in Legrand 167 's errata (London, 1626 ?), Ar ${ }^{\mathrm{r}}$.

Headpiece $(28 \times 101 \mathrm{~mm})$, boy's head and three fish in the middle, flanked by dragon heads, squirrels and cherubs on each side. It appears in: Aristotle, Rhetorica (1619), STC 766, 2I $2^{\mathrm{r}}$; George Goodwin, Melissa religionis pontificia (1620), STC $12029, \mathrm{A2}^{\mathrm{r}}, \mathrm{Br}^{\mathrm{r}}$; John Boys, Works (1622), STC $345^{2}$, Gr $\mathrm{Gr}^{\mathrm{r}}$, ${ }_{2} \mathrm{Q}_{1} \mathrm{r}, 3 \mathrm{~W}_{3},{ }_{4}^{\mathrm{r}} \mathrm{Ll}^{\mathrm{r}}$; Francis White, The Orthodox Faith (1624), STC $25381, \mathrm{~B}^{\mathrm{r}}$,

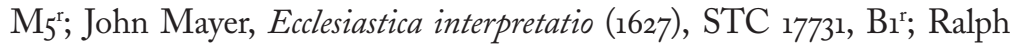
Knevet, A Discourse of Military Discipline (1628), STC 15037, D2 ${ }^{\mathrm{r}}$; Sebastian Benefield, $A$ Commentarie (1629), STC 1862, C1 $1^{\mathrm{r}}$. Metaxas used it in Legrand 168a (London, 1626?), Arr ; Legrand 168b (London, 1626?), A $\mathrm{r}^{\mathrm{r}}$; Legrand ${ }_{168} \mathrm{c}$ (London, 1626?), $\mathrm{Al}_{\mathrm{r}^{\mathrm{r}}}$

Headpiece $(25 \times 91 \mathrm{~mm})$, urn overflowing with flowers and four birds perching on the branches. It appears in: Daniel Featley, A Second Parallel (1626), STC 10737, $\mathrm{Cl}^{\mathrm{r}}$; John Mayer, Ecclesiastica interpretatio (1627), STC ${ }_{17731}, \mathrm{P}_{3}{ }^{\mathrm{r}}$; William Foster, The Means to Keep Sin from Reigning in our Mortal Body (1629), STC 11204, $\mathrm{A}_{3}{ }^{\mathrm{r}}$. Metaxas used it in Legrand 168a (London, 1626?), Arr.

The fonts employed for Legrand 168 were the same as the two fonts Metaxas purchased to take to Constantinople: 1) the $114 \mathrm{~mm}$ great primer bought from Jones; and 2) the $87 \mathrm{~mm}$ Haultin-like pica that once belonged to Eliot's Court Press. During the printing of Legrand 168, which was the last book he published in London, Metaxas added further ornaments to his inventory. I believe Metaxas's main contact at the Eliot's Court Press was John Haviland, as it is his name that appears in the false imprint of Legrand 143 actually printed in Cephalonia. He also acquired three initials from Haviland:

55. For more information on Eliot's Court Press, see Robert Plomer, "The E1iot's Court Printing-House, 1584-1674," The Library 4, no. 2 (1921): 175-84; Robert Plomer, "Eliot's Court Press: Decorative Blocks and Initials," The Library 4, no. 3 (1922): 194-209. 
Floriated initial "A" $(26 \times 26 \mathrm{~mm})$. It appears in: Patrick Hannay, The Nightingale Sheretine and Mariana (1622), STC 12748, F8 ${ }^{\mathrm{r}}, \mathrm{N} 6^{\mathrm{r}}$; William Gouge, Of Domestical Duties (1622), STC 12119, $\mathrm{Br}^{\mathrm{r}}, \mathrm{Z}_{7}$; Francis Bacon, Essays (1625), STC $1148, \mathrm{~S}_{4}{ }^{\mathrm{r}},{ }_{2} \mathrm{Fr}^{\mathrm{v}},{ }_{2} \mathrm{I}_{4}^{\mathrm{r}}$; William Browne, Britannia's Pastorals (1625), STC 3916, L7 $7^{\mathrm{r}}$. Metaxas used it in Legrand 166a (Constan-

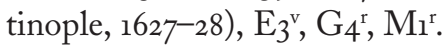

Floriated initial "H" $(22 \times 22 \mathrm{~mm})$. It appears in: Nehemiah Rogers, $A$ Strange Vineyard in Palastina (1625), STC 21199, A $5^{\mathrm{r}}$; Elizabeth Joceline, A Mother's Legacy (1625), STC $14625, \mathrm{Bi}^{\mathrm{r}}$. Metaxas used it in Legrand 143 (Cephalonia, 1628?), $\mathrm{A}_{3}{ }^{\mathrm{r}}$.

Floriated initial "I" $(29 \times 29 \mathrm{~mm})$. It appears in: Patrick Hannay, The Nightingale Sheretine and Mariana (1622), STC ${ }_{12748}, \mathrm{P}_{3}{ }^{\mathrm{r}}$; William Gouge, Of Domestical Duties (1622), STC 12119, $\mathbf{q}_{2}{ }^{\mathrm{r}}, \mathrm{S}^{\mathrm{r}},{ }_{2} \mathrm{~T}_{3}^{\mathrm{v}}$; Francis Bacon, Essays (1625), STC 1148, throughout. Metaxas used it in Legrand 166a (Constantinople, 1627-28), $\mathrm{Al}^{\mathrm{r}}$.

In London, Metaxas collaborated with Stansby, Jones, and Eliot's Court Press, purchased type and ornaments from Jones and Haviland; yet these associations do not account for all the printing equipment and type ornaments he transferred to and used in Constantinople and Cephalonia. For instance, the coat-of-arms used as a printer's device for Legrand 166 and Legrand 143 did not belong to any of these printing houses rather but to Augustine Matthews. ${ }^{56}$ The woodcut's design features the arms of England and Wales (1603-1649) with the Order of the Garter motto "Honi soit qui mal y pense." While very many heraldic woodcuts with similar designs feature in the proclamations and other royal notices from this period, this particular woodcut appeared in a single document: a broadsheet advertisement for plague remedies ascribed to Matthews. ${ }^{57}$ The broadsheet is datable to 1625 , the year when

56. Metaxas and Matthews had no formal association nor did they publish together, but an important aspect that brought the two men together-other than their financial dealings - could have been the nature of their publications. During the $1620 s$, Matthews was predominantly publishing anti-Catholic books, including treatises, sermons, and other polemical works attacking Roman Catholicism, while Metaxas was printing the anti-Latin manuscripts he had in his possession.

57. STC 6901.5. See Robert Lemon, Catalogue of a Collection of Broadsides in the Possession of the Society of Antiquaries of London (London: The Society of Antiquaries, 1886), 76 (no. 265); Robert Steele, Tudor and Stuart Proclamations 1485-1714, 2 vols. (Oxford: Clarendon Press, 1910), 1:169. 
another epidemic of the Black Death swept across London. ${ }^{58}$ Metaxas, therefore, must have acquired the woodcut in or after 1625 and taken it with him to Constantinople. It may seem curious that he chose to use this design as his printer's device for the volumes he printed in the Ottoman capital. His motivation, arguably, was political, namely to "arm" his book visually with the royal coat-of-arms, thus placing it under the perceived protection of the English king against possible enemies. ${ }^{59}$ The only elaborate head piece purchased by Metaxas, a floriated ornament with a winged figurehead in the middle, which appeared in Legrand 166 and Legrand 143, also belonged to Matthews, who used it only once, in $1622 .{ }^{60}$

Rareness of use is a common characteristic among the blocks Metaxas purchased. The historiated initial $\Omega$ with a woman's head and the initial $\Delta$ of unknown provenance proved impossible to find in my survey of all the registered Greek books published in London until 1630. ${ }^{61}$ Similarly, the initial $\Pi$ with the lute figure had only been used once by Jones before Legrand 167. John Day's initial $Y^{2}$ had been used once in 1561 and once in 1591 by Abell Jeffes. ${ }^{62}$ The block lay dormant until Metaxas recycled it some 35 years later. ${ }^{63}$ It would not be wrong to assume that Metaxas's preference for obsolete printing material stemmed from necessity rather than choice. Having paid the costs himself, and without any promise of a reimbursement for his expenses, Metaxas would have been wise to seek budget-friendly or free options. And the woodcuts he eventually

58. See Stephen Greenberg, "Plague, the Printing Press, and Public Health in Seventeenth-Century London," Huntington Librarv Ouarterly 67, no. 4 (2004): 508-527; Ryan J. Hackenbracht, "The Plague of 1625-26, Apocalyptic Anticipation, and Milton's Elegy III," Studies in Philology 108, no. 3 (2011): 403-38.

59. Whether Metaxas's publishing activities in London had received royal sanction remains unclear, but an association with Peter Young, who would later become a partner of the King's Press, through Metrophanes Critopoulos, is possible. On Critopoulos's letters to Young see Johannes Kemke, Patricius Junius (Patrick Young) bibliothekar der könige Jacob I. und Karl I. von England (Leipzig: M. Spirgatis, 1898), 125. On the petitions Critopoulos handed to King James I, see Davey, Pioneer for Unity, 112-14.

6o. Michael Drayton, The Second Part, or a Continuance of Poly-Olbion (1622), STC $7230, \mathrm{Al}_{1}^{\mathrm{r}}, \mathrm{Y}_{1}^{\mathrm{r}}$.

61. $\Omega$ : Legrand $167 \mathrm{a}, \mathrm{F}_{4}^{\mathrm{r}}$; Legrand $166 \mathrm{~b}, \mathrm{C}_{2}^{\mathrm{v}}$.

62. Day: STC 19848, $\mathrm{N}_{1}^{\mathrm{r}}$ (see Oastler, John Day). Jeffes: STC 6859, B8 ${ }^{\mathrm{r}}, \mathrm{C}_{4}^{\mathrm{r}}, \mathrm{C}_{5}^{\mathrm{v}}$. 63. Legrand 166b, $\mathrm{Al}^{\mathrm{r}}$. 
purchased had long become obscure, hence cheaper-they might have even been given away gratis by his printer friends as tokens of amity. The same goes for the typefaces he obtained, for both the Haultin-like pica Greek and Haultin's great primer Greek had already gone out of favor with Jones and other London printers by the 1620 s.

The printing press was the most important item acquired by Metaxas, and the arrival of such exotic machinery in Constantinople did not go unnoticed. Sir Thomas Roe, the English ambassador to the Porte, who was present at the seaport to oversee the unloading of the trade goods, commented:

As soone as [Metaxas] came ashore, and had spoken with the Patriarch ... and they both came to acquaynt me with this charitable entention, and to desire my help and protection to take up the stamp, and to pass it as my goods; which being very heavye, could not be done without suspition. ${ }^{64}$

A report from Venier touches upon the difficulties Metaxas experienced with the export of the press from England: "I was told . . . that [Metaxas] had exported the press thanks to a great favor, as there are severe restrictions with regards to that matter in that Kingdom." ${ }^{65}$

In the first half of the seventeenth century, England still lagged behind the Continent in terms of technical advancements in printing: the woodcuts were crude, metalwork was second quality, and most importantly, almost all materials, including punches for casting type, were imported at great cost. Importing a press and punches to cast type would have been expensive and time-consuming, therefore Metaxas sought to source his materials locally. Presses were often passed down from one printer to the other, and they were not exceptionally costly. Sheila Lambert documented that 11 guineas were paid at Cambridge for a second-hand press in the early eighteenth century, while a new one in the seventeenth century would have cost about £10. She also notes that Richard Badger paid £.14 2s. for a press and letters in 1629, while

64. Negotiations, 760.

65. "mi narrò ... che la stampa . . . per gran favore si era estratta da quel regno, essendovene severe prohibitioni" (4 September 1627, Venice, State Archives, Dispacci Constantinopoli, 105.47, ff. $67^{\mathrm{r}}-7 \mathrm{r}^{\mathrm{r}}$, reproduced in Augliera, Libri, politica, religione, 44-48, 46). 
Jane Coe's press and letters (a few hundred kilos of worn type) changed hands in 1647 for $£_{72} 17 \mathrm{~s} .{ }^{66}$

It is likely that Metaxas bought a press from a printer whose business went bust in 1627 , although printers also disposed of presses when the Stationers' Company ordered them to do so. The 1586 Star Chamber Decree was the first attempt to limit the number of master printers in the capital and the production presses in their possession. ${ }^{67}$ The Stationers' Company minutes of 9 March 1615 clearly stated that, excepting the King's Printer, out of the nineteen printers, fourteen were allowed two presses, and the rest were allowed only one. ${ }^{68}$ McKenzie felt that the rules limiting the number of presses were generally ignored, while Fredson Bowers asserted that "the number of presses was rigidly controlled by inspection." ${ }^{69}$ Giving leeway to both assumptions and based on the evidence from the printing house of Nicholas Oakes, Blayney concludes that while at least some printers "faithfully adhered" to the rules for limited periods of time, the inspections were "insufficient to stop the illicit use of a second press." ${ }^{\text {70 }}$

According to the Stationers' Company minutes of 5 July 1623, of those printers associated with Metaxas, Stansby was granted permission to keep two presses, Haviland and Mrs. Griffin two presses, and Jones only one. Despite the dubious nature of his master-printer status, Matthews was also allowed to keep one press (that passed to him from Edward White) in his shop located in St. Bride's Lane, near Fleet Street. ${ }^{71}$ Yet, like many other London printers, he offended the company restrictions several times by keeping more than one press in production. ${ }^{72} \mathrm{On}$

66. Lambert, "Journeymen and Master Printers," 22.

67. Edward Arber, A Transcript of the Registers of the Company of Stationers of London, 1557-1640, 5 vols. (London and Birmingham: Privately Printed, 1875-94), 2:807.

68. Ibid., 3:699.

69. McKenzie, "Printers of the Mind," 53-56. Fredson Bowers, "McKerrow Revisited," PBSA 67 (1973): 119 .

70. Peter W. M. Blayney, "The Prevalence of Shared Printing in the Early Seventeenth Century," PBSA 67 (1973): 441-42.

71. Jackson, Records, 158 .

72. This was not the only illegal activity Matthews was engaged in. Jackson records that on 4 June 1621 he was fined for publishing illicit material (Records, 135). See also David McKitterick, A History of Cambridge University Press: Printing and 
${ }_{27}$ May 1623, the Stationers' court ruled that the unlawful press belonging to Matthews at Bunhill "shall be taken down." ${ }^{73}$ On 5 July the same year, it was "ordered that Matthews shall take down one of his presses and bring it into the hall." ${ }^{\prime 4}$ Between this date and the summer of 1628 , a number of other unlicensed presses were also "destroyed or dismantled" by company orders. ${ }^{75}$ So, demonstrably, it was not extraordinary at all to find redundant presses and defunct printing material in 1620 s London. One of these redundant presses may well have come into the possession of Metaxas or anyone else who wanted to print privately.

Finally, the reports from Constantinople indicate that Metaxas took with him either one or two skilled workmen who would ensure the smooth running of his new enterprise. Venier wrote that Metaxas had brought with him "a Fleming master," while the English ambassador Roe reported that there were "two Dutchmen to order it, and to teach the use" on board the Royal Defense, the ship that carried Metaxas to the Ottoman capital. ${ }^{76}$ Various scholars argue, albeit without producing any solid evidence, that Metaxas might have recruited the operators while passing through the Low Countries on his way to Constantinople. ${ }^{77}$ This is most unlikely in the face of Roe's report that Metaxas arrived in Constantinople by sea, on board Royal Defence, a trade vessel that belonged to the Levant Company ${ }^{78}$ However, these skilled foreign workers could not have appeared out of the blue in Constantinople either, as printing had not yet become a sustainable trade in the city. It is much more likely that Nikodemos met and employed the two Dutch/

the Book Trade in Cambridge, 1534-1698 (Cambridge: Cambridge University Press, 1992), 166.

73. Jackson, Records, 159. See also Percy Simpson, Studies in Elizabethan Drama (Folcroft, PA: Folcroft Library Editions, 1971), 246; McKitterick, A History, 166; McKenzie, "Printers of the Mind," 56.

74. Jackson, Records, 159 .

75. Ibid., 158-59, 173, 194 .

76. "e un perito per introdur la stampa pur de libri greci solamente in questa città ... . et che haveva un fiamengo per maestro" (4 September 1627, Venice, State Archives, Dispacci Constantinopoli, 105.47, ff. $67^{\mathrm{r}}-7 \mathrm{1}^{\mathrm{r}}$, reproduced in Augliera, Libri, politica, religione, 44-48, 45, 46); Negotiations, 663 .

77. Layton, "Nikodemos Metaxas," 140-41; Augliera, Libri, politica, religione, 10; Keetje Rozemond, "De Drukkerij van Nikodemos Metaxas in Konstantinopel (1627-1628)," Het Boek 37 (1964/65), 85.

78. Negotiations, 760 . 
Flemish workers in London, since it was not unusual at all to find aliens working in the printing trade in London. Three of the printers Metaxas had dealings with received at least one warning from the Company for hiring alien workers. On 18 August 1624, Stansby was warned "to put away Peter Smith and Jeremy Maidstone, 2 foreigners within 8 days." 79 Jones was likewise told "to put away a journeyman not free, that he keeps disorderly upon the pain of the penalty in that case provided." 80 Matthews, too, was among those London printers who employed foreign workforce and was ordered numerous times to expel the apprentices whom he kept against the law. The first warning was issued on ${ }_{25}$ September 1620, ordering Matthews "to discard Frances Gastonie, a foreigner." ${ }^{\prime 1}$ On 21 November 1622, 18 August 1624 and in April 1627, Matthews was repeatedly ordered to discard his illegal foreign apprentices. ${ }^{82}$ In view of all this, a connection between foreign operators who had been made redundant in London, and Metaxas's Dutch/Flemish workers who appeared on the shores of Constantinople aboard an English ship, seems plausible.

Throughout this article, I have tried to demonstrate, through a case study of Metaxas's activities, how a man of letters from abroad, a monk of noble origin with ambitions to publish, would have navigated his way through the paper merchants, master printers, and other members of the printed book trade in seventeenth-century London. I have shown that each and every material trace Metaxas left behind through his purchases of typographic equipment offers students of analytical bibliography a glimpse into the web of human and financial relations governing the London printing trade. Metaxas was no inky-fingered craftsman. He was a learned man who edited Byzantine texts, compiled the correspondence of ancient worthies, and penned letters in Attic Greek to patrons in high places. Yet, he also became knowledgeable in the mechanical aspects of printing thanks to the hands-on experience he gained in London's pioneering printing houses. Each book Metaxas produced records his growth as an independent printer, publisher, and editor of books.

79. Jackson, Records, 169 .

8o. Ibid.

81. Ibid., 131.

82. Ibid., 151, 169, and 194 . 
In Angelos's frustration with his Oxford printers and his preference for Stansby's printing house we have seen that provincial and London printers offered varying degrees of typographical quality. Through a closer examination of paratextual material of Angelos and Metaxas's books (prefaces, notes, errata lists, and so on) we have also seen the complications of printing in England in a foreign language and nonLatin type. Finally, in Metaxas's preference for London as his chosen destination to print Orthodox Greek tracts, we have seen that England, despite the country's limitations with regards to printing materials and workforce, was regarded by some, and especially those fleeing the oppression of Roman Catholicism, as a safe haven for publishing. Answering the question whether London was on the map for those who aspired to print privately, or whether Metaxas's printing venture in London was an isolated case, remains an area for further exploration. 